\title{
Serum Prognostic Factors of Androgen-deprivation Therapy Among Japanese Men With De Novo Metastatic Prostate Cancer
}

\author{
TAKESHI KOBAYASHI, RYO NAMITOME, YU HIRATA, MASAKI SHIOTA, KENJIRO IMADA, \\ EIJI KASHIWAGI, ARIO TAKEUCHI, JUNICHI INOKUCHI, KATSUNORI TATSUGAMI and MASATOSHI ETO \\ Department of Urology, Graduate School of Medical Sciences, Kyushu University, Fukuoka, Japan
}

\begin{abstract}
Background/Aim: To date, several serum prognostic factors have been reported in metastatic prostate cancer. In this study, we examined the prognostic value of these serum markers in Japanese men. Patients and Methods: This study included 104 patients with metastatic prostate cancer who were treated with primary androgen-deprivation therapy from 2001 to 2013. Clinicopathological factors including several serum markers were investigated for association with progression-free (PFS) and overall (OS) survival. Results: During a median follow-up of 48.1 months, median PFS and OS were 24.0 months and 67.4 months, respectively. When adjusted by age, prostate-specific antigen at diagnosis, Gleason score, and clinical stage, serum lactate dehydrogenase value was significantly associated with PFS [hazard ratio $(H R)=1.42$, 95\% confidence interval $(C I)=1.15-1.74 ; p=0.0004]$ and $O S$ ( $H R=1.46,95 \% C I=1.13-1.82 ; p=0.0014)$, in addition to alkaline phosphatase value for OS (HR=1.04; 95\% CI=1.001.07; $p=0.015)$. Conclusion: This study demonstrates the prognostic significance of alkaline phosphatase and lactate dehydrogenase values in Japanese men with de novo metastatic hormone-sensitive prostate cancer.
\end{abstract}

Androgen-deprivation therapy (ADT) has been the standard treatment for recurrent or advanced prostate cancer since 1941 (1). In 2015, docetaxel chemotherapy with ADT for metastatic hormone-sensitive prostate cancer (HSPC) was shown to prolong both time to progression and overall survival (OS) in the CHAARTED and STAMPEDE trials (2, 3 ). In addition, survival benefit from the cytochrome $P 450$ family 17 subfamily inhibitor abiraterone with ADT for

Correspondence to: Masaki Shiota, MD, Ph.D., Department of Urology, Graduate School of Medical Sciences, Kyushu University, 3-1-1 Maidashi, Higashi-ku, Fukuoka 812-8582, Japan. Tel: +81 926425603, Fax: +81 926425618, e-mail: shiota@uro.med.kyushuu.ac.jp

Key Words: Androgen-deprivation therapy, ALP, LDH, metastatic prostate cancer. metastatic HSPC was also demonstrated in the LATITUDE and STAMPEDE trials in $2017(4,5)$. Accordingly, up-front docetaxel chemotherapy and abiraterone with ADT have become standard therapies for metastatic HSPC (6).

To date, several prognostic factors in ADT have been reported. In addition to utilization of single parameters, the Glass model, which incorporates metastatic site, performance status, Gleason score and prostate-specific antigen (PSA) level, was classically proposed as a prognostic model using these multiple prognostic factors in combination. Later, the J-CAPRA score, which includes clinical TNM stage, Gleason score and PSA level, was developed to more accurately predict prognosis (7). In addition to these clinicopathological prognostic characteristics, several serum parameters were reported to be prognostic in various cancer types. Among them, hemoglobin ( $\mathrm{Hb}$ ), alkaline phosphatase (ALP), and lactate dehydrogenase (LDH) are well known (8). In addition, inflammatory parameters of serum, such as the neutrophil-lymphocyte ratio (NLR) and C-reactive protein (CRP) as well as sodium were recently suggested to be prognostic (9-11). In this study, we aimed to examine the significance of these serum parameters in Japanese men with de novo metastatic prostate cancer treated with ADT.

\section{Patients and Methods}

Patients. This study retrospectively enrolled 104 Japanese men who were treated with primary ADT for de novo metastatic prostate cancer at Kyushu University Hospital, Fukuoka, Japan, from 2001 to 2013, for whom any serum parameters were available. We excluded: (i) patients of any ethnicity other than Japanese; (ii) patients who had received local treatment before primary ADT; and (iii) patients who received other treatments (such as chemotherapy) before disease progression. This study was approved by the Institutional Review Board of Kyushu University Hospital (29-438). All patients were histopathologically diagnosed with adenocarcinoma of the prostate, including 93 men (89.4\%) who were biopsied at Kyushu University Hospital and 11 men $(10.6 \%)$ who were biopsied at another institution (three biopsy specimens of which were reviewed at our Institution). Clinical staging was determined using the unified TNM criteria based on results of digital rectal examinations, transrectal ultrasound, magnetic resonance imaging, computed tomography, and bone scans (12). 
Table I. Patient characteristics.

\begin{tabular}{|c|c|c|}
\hline Characteristic & & $\mathrm{n}=104$ \\
\hline Age, years & Median (IQR) & $72(68-77)$ \\
\hline PSA at diagnosis, $\mathrm{ng} / \mathrm{ml}$ & Median (IQR) & $209.5(73.8-524.3)$ \\
\hline \multirow[t]{2}{*}{ Gleason score, $\mathrm{n}(\%)$} & $\leq 7$ & $16(15.4 \%)$ \\
\hline & $8-10$ & $88(84.6 \%)$ \\
\hline \multirow[t]{3}{*}{ cT stage, n (\%) } & $\mathrm{T} 2 / 3 \mathrm{a}$ & $40(38.5 \%)$ \\
\hline & $\mathrm{T} 3 \mathrm{~b}$ & $29(27.9 \%)$ \\
\hline & $\mathrm{T} 4$ & $35(33.7 \%)$ \\
\hline \multirow[t]{2}{*}{$\mathrm{cN}$ stage, $\mathrm{n}(\%)$} & No & $39(37.5 \%)$ \\
\hline & N1 & $65(62.5 \%)$ \\
\hline \multirow[t]{3}{*}{ cM stage, n (\%) } & M1a & $8(7.7 \%)$ \\
\hline & M1b & $92(88.5 \%)$ \\
\hline & M1c & $4(3.8 \%)$ \\
\hline $\mathrm{Hb}$ at diagnosis, $\mathrm{ng} / \mathrm{ml}$ & Median (IQR) & $13.6(12.7-14.4)$ \\
\hline \multirow[t]{2}{*}{ NLR at diagnosis } & Median (IQR) & $2.5(1.8-3.5)$ \\
\hline & $\mathrm{NA}, \mathrm{n}$ & 5 \\
\hline ALP at diagnosis, $\mathrm{U} / 1$ & Median (IQR) & $304(217-546)$ \\
\hline \multirow[t]{2}{*}{$\mathrm{LDH}$ at diagnosis, $\mathrm{U} / 1$} & Median (IQR) & $202(181-247)$ \\
\hline & $\mathrm{NA}, \mathrm{n}$ & 10 \\
\hline \multirow[t]{2}{*}{$\mathrm{Na}$ at diagnosis, $\mathrm{mmol} / \mathrm{l}$} & Median (IQR) & $140(139-142)$ \\
\hline & $\mathrm{NA}, \mathrm{n}$ & 14 \\
\hline \multirow[t]{2}{*}{$\mathrm{CRP}$ at diagnosis, $\mathrm{mg} / \mathrm{dl}$} & Median (IQR) & $0.16(0.06-0.66)$ \\
\hline & $\mathrm{NA}, \mathrm{n}$ & 4 \\
\hline
\end{tabular}

PSA: Prostate-specific antigen; Hb: hemoglobin; NLR: neutrophillymphocyte ratio; ALP: alkaline phosphatase; LDH: lactate dehydrogenase; Na: sodium; CRP: C-reactive protein.

Treatment and outcome. All patients were primarily treated with ADT with surgical castration, or medical castration using a luteinizing hormone-releasing hormone agonist/antagonist (goserelin acetate, leuprorelin acetate, or degarelix acetate) with/without an anti-androgen agent (bicalutamide or flutamide); 98 men were primarily treated with combined androgen blockade, and six men were treated with castration alone. Progression was judged by a PSA increase of $>2 \mathrm{ng} / \mathrm{ml}$ and a $25 \%$ increase over the nadir, or radiographic progression defined as the appearance of two new lesions or progression of one or more known lesions, as classified by the Response Evaluation Criteria in Solid Tumours (RECIST) (13).

Statistical analysis. All statistical analyses were performed using JMP13 software (SAS Institute, Cary, NC, USA). Continuous and categorical data were analyzed by Wilcoxon rank-sum and Pearson's chi-square tests, respectively. Survival analyses were conducted using the Kaplan-Meier method and log-rank test. The Cox proportional hazards model was used to estimate hazard ratios (HRs). All $p$-values were two-sided; values of $p<0.05$ were considered significant.

\section{Results}

During a median follow-up of 48.1 months (interquartile range $=25.0-68.4$ months), 72 men (69.2\%) experienced progression to castration-resistant prostate cancer (CRPC) and

\section{A}

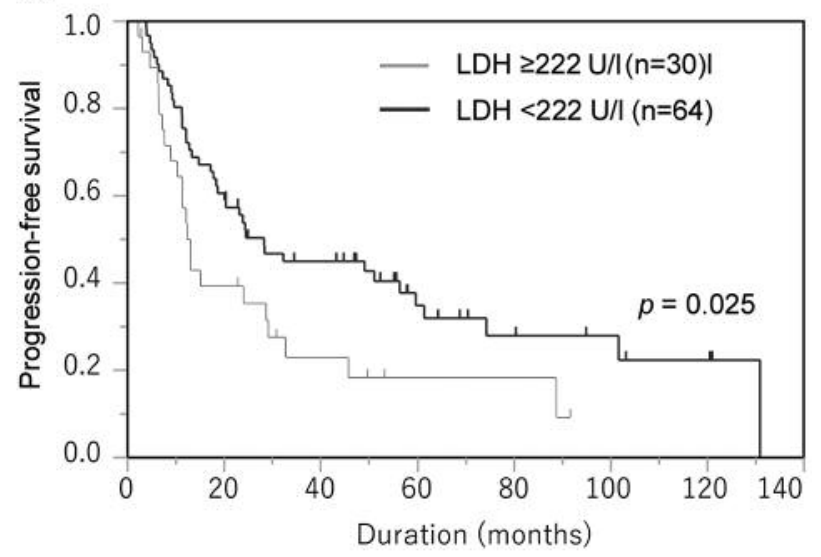

B

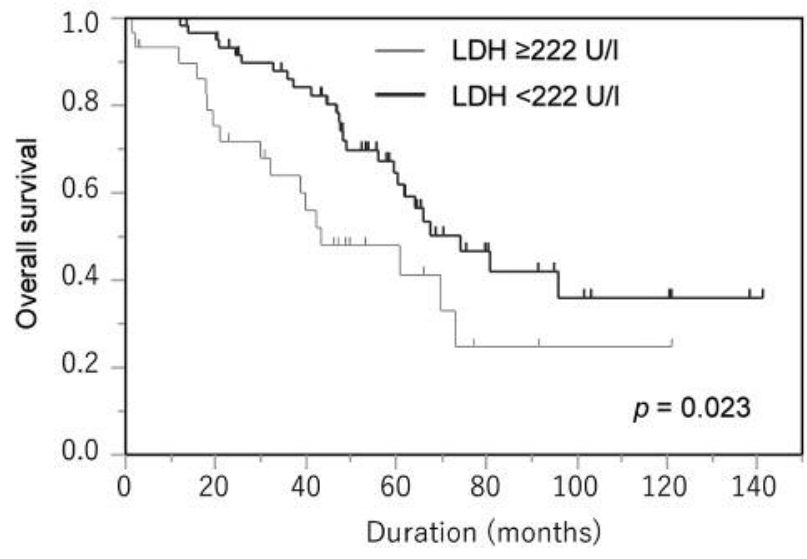

Figure 1. Prognosis according to serum lactate dehydrogenase ( $L D H)$ value among men with metastatic prostate cancer. Progression-free survival (A) and overall survival (B) according to serum $L D H$ value using the upper limit of normal as a cut-off.

48 men (46.2\%) died from any cause. Median PFS and OS were 24.0 months (interquartile range=11.3-74.1 months) and 67.4 months (interquartile range $=43.3$ months-not reached), respectively. Most patients presented with high PSA levels, high Gleason score, and advanced TNM stage at initial diagnosis (Table I). Hb, NLR, ALP, LDH, sodium, and CRP values were within a normal range for most patients (Table I).

Next, the prognostic significance of clinicopathological factors including serum parameters for PFS were evaluated. As shown previously, Gleason score, clinical T-stage, and clinical N-stage were identified to be prognostic, although the PSA level at diagnosis and clinical M-stage were not prognostic in this cohort (Table II). Among serum parameters, only a high LDH level was identified as being associated with an increased risk of progression to CRPC on univariate analysis $(\mathrm{HR}=1.45,95 \%$ confidence interval 
Table II. Univariate and multivariate analyses for progression-free survival.

\begin{tabular}{|c|c|c|c|c|c|}
\hline \multirow[t]{2}{*}{ Variable } & & \multicolumn{2}{|c|}{ Univariate } & \multicolumn{2}{|c|}{ Multivariate } \\
\hline & & $\mathrm{HR}(95 \% \mathrm{CI})$ & $p$-Value & HR $(95 \%$ CI) & $p$-Value \\
\hline Age & Per unit & $1.03(0.99-1.07)$ & 0.11 & & \\
\hline PSA at diagnosis & Per 100 units & $1.01(0.99-1.02)$ & 0.50 & & \\
\hline \multirow[t]{2}{*}{ Gleason score } & $\leq 7$ & Ref & & & \\
\hline & $8-10$ & $2.04(1.03-4.65)$ & 0.039 & & \\
\hline \multirow{3}{*}{ cT stage } & $\mathrm{T} 2 / 3 \mathrm{a}$ & Ref & & & \\
\hline & $\mathrm{T} 3 \mathrm{~b}$ & $1.39(0.75-2.58)$ & 0.30 & & \\
\hline & $\mathrm{T} 4$ & $2.85(1.62-5.12)$ & 0.0003 & & \\
\hline \multirow[t]{2}{*}{$\mathrm{cN}$ stage } & No & Ref & & & \\
\hline & N1 & $1.64(1.00-2.76)$ & 0.048 & & \\
\hline \multirow[t]{3}{*}{ cM stage } & M1a & Ref & & & \\
\hline & M1b & $1.53(0.68-4.38)$ & 0.33 & & \\
\hline & M1c & $0.60(0.031-3.74)$ & 0.63 & & \\
\hline $\mathrm{Hb}$ at diagnosis & Per unit & $0.94(0.80-1.11)$ & 0.45 & $0.93(0.75-1.16)$ & 0.54 \\
\hline NLR at diagnosis & Per unit & $0.96(0.81-1.12)$ & 0.64 & $0.96(0.80-1.14)$ & 0.68 \\
\hline ALP at diagnosis & Per 100 units & $1.01(0.98-1.03)$ & 0.49 & $1.02(0.99-1.04)$ & 0.16 \\
\hline $\mathrm{LDH}$ at diagnosis & Per 100 units & $1.45(1.18-1.75)$ & 0.0009 & $1.42(1.15-1.74)$ & 0.0004 \\
\hline $\mathrm{Na}$ at diagnosis & Per unit & $0.94(0.84-1.05)$ & 0.30 & $0.97(0.86-1.09)$ & 0.63 \\
\hline $\mathrm{CRP}$ at diagnosis & Per unit & $1.05(0.91-1.16)$ & 0.45 & $1.10(0.94-1.24)$ & 0.18 \\
\hline
\end{tabular}

PSA: Prostate-specific antigen; Hb: hemoglobin; NLR: neutrophil-lymphocyte ratio; ALP: alkaline phosphatase; LDH: lactate dehydrogenase; Na: sodium; CRP: c-reactive protein. Significant $p$-values are shown in bold.

$(\mathrm{CI})=1.18-1.75 ; p=0.0009)$, which was confirmed on multivariate analysis adjusted by age, PSA at diagnosis, Gleason score, and clinical stage $(\mathrm{HR}=1.42,95 \% \mathrm{CI}=1.15$ $1.74 ; p=0.0004$ ) (Figure 1A, Table II).

Similar results were obtained for OS. As previously reported, age, Gleason score, and clinical T-stage were identified to be prognostic, although the PSA level at diagnosis, clinical $\mathrm{N}$-stage and clinical M-stage were not prognostic in this cohort (Table III). Among serum parameters, low $\mathrm{Hb}(\mathrm{HR}=0.78,95 \% \mathrm{CI}=0.64-0.96 ; p=0.020)$, high $\mathrm{LDH}(\mathrm{HR}=1.32,95 \% \mathrm{CI}=1.03-1.62 ; p=0.028)$ and low $\mathrm{Na}(\mathrm{HR}=0.86,95 \% \mathrm{CI}=0.75-0.99 ; p=0.029)$ values were identified as associated with increased death risk by any cause on univariate analysis. However, when adjusted by age, PSA at diagnosis, Gleason score, clinical stage, ALP value $[\mathrm{HR}=1.04,95 \% \mathrm{CI}=1.00-1.07 ; p=0.015]$ and $\mathrm{LDH}$ value $[\mathrm{HR}=1.46,95 \% \mathrm{CI}=1.13-1.82 ; p=0.0014]$ were identified to be prognostic for OS (Figure 1B, Table III).

\section{Discussion}

This study showed that the ALP level was a prognostic factor for OS, but not for PFS. Moreover, the LDH level was identified as a robust and prominent prognostic factor for both PFS and OS. However, Hb, NLR, sodium, and CRP values failed to be associated with prognosis.

Recently, Gravis et al. showed that the serum ALP value is the most prominent prognostic factor for OS among men treated with ADT with or without docetaxel in the GETUGAFU15 trial, which mainly enrolled Caucasian patients (8). Similarly, in Asian populations including Japanese, Chinese and Korean individuals, it was reported that a high ALP level was associated with worse prognosis in metastatic HSPC (14-16). The ALP value is associated with the extent of disease in bone metastasis, which is also a well-known prognostic factor for OS (16-18). The ALP value, however, was not prognostic for PFS. Intriguingly, ALP was shown to be a prognostic factor in patients with CRPC when treated with docetaxel and androgen receptor axis-targeting agents such as abiraterone and enzalutamide (19, 20). Therefore, differential prognostic significance for PFS and OS may be explained by the prognostic value of ALP in CRPC.

The LDH value has also been reported to be prognostic for OS in HSPC. Gravis et al. demonstrated that the LDH value in addition to the ALP value is a prognostic factor for OS among men treated with ADT in the GETUG-AFU15 trial (8). Similarly, in an Asian population of Japanese, Chinese and Korean individuals, it was reported that a high LDH level was associated with worse prognosis in metastatic HSPC $(15,16,21)$. A high $\mathrm{LDH}$ value seems to originate from cancer cells in most patients, reflecting the total cancer volume, although the ALP level mirrors only bony lesions of prostate cancer. Therefore, LDH may reflect the whole-body cancer status more accurately than ALP, resulting in more precise prognostic ability. 
Table III. Univariate and multivariate analyses for overall survival.

\begin{tabular}{|c|c|c|c|c|c|}
\hline \multirow[t]{2}{*}{ Variable } & & \multicolumn{2}{|c|}{ Univariate } & \multicolumn{2}{|c|}{ Multivariate } \\
\hline & & HR $(95 \% \mathrm{CI})$ & $p$-Value & HR $(95 \% \mathrm{CI})$ & $p$-Value \\
\hline Age & Per unit & $1.07(1.02-1.12)$ & 0.0045 & & \\
\hline PSA at diagnosis & Per 100 units & $1.01(0.99-1.03)$ & 0.33 & & \\
\hline \multirow[t]{2}{*}{ Gleason score } & $\leq 7$ & ref & & & \\
\hline & $8-10$ & $3.62(1.32-14.99)$ & 0.0095 & & \\
\hline \multirow[t]{3}{*}{ cT stage } & $\mathrm{T} 2 / 3 \mathrm{a}$ & ref & & & \\
\hline & $\mathrm{T} 3 \mathrm{~b}$ & $1.33(0.62-2.86)$ & 0.46 & & \\
\hline & $\mathrm{T} 4$ & $2.42(1.22-4.98)$ & 0.011 & & \\
\hline \multirow[t]{2}{*}{$\mathrm{cN}$ stage } & No & ref & & & \\
\hline & $\mathrm{N} 1$ & $1.13(0.63-2.11)$ & 0.69 & & \\
\hline \multirow[t]{3}{*}{ cM stage } & M1a & ref & & & \\
\hline & M1b & $1.04(0.42-3.46)$ & 0.94 & & \\
\hline & M1c & $1.25(0.064-8.61)$ & 0.84 & & \\
\hline $\mathrm{Hb}$ at diagnosis & Per unit & $0.78(0.64-0.96)$ & 0.020 & $0.80(0.60-1.06)$ & 0.11 \\
\hline NLR at diagnosis & Per unit & $0.85(0.67-1.03)$ & 0.098 & $0.85(0.67-1.09)$ & 0.20 \\
\hline ALP at diagnosis & Per 100 units & $1.02(0.99-1.05)$ & 0.17 & $1.04(1.00-1.07)$ & 0.015 \\
\hline $\mathrm{LDH}$ at diagnosis & Per 100 units & $1.32(1.03-1.62)$ & 0.028 & $1.46(1.13-1.82)$ & 0.0014 \\
\hline $\mathrm{Na}$ at diagnosis & Per unit & $0.86(0.75-0.99)$ & 0.029 & $0.89(0.77-1.03)$ & 0.12 \\
\hline $\mathrm{CRP}$ at diagnosis & Per unit & $1.05(0.89-1.19)$ & 0.49 & $1.17(0.96-1.35)$ & 0.070 \\
\hline
\end{tabular}

PSA: Prostate-specific antigen; Hb: hemoglobin; NLR: neutrophil-lymphocyte ratio; ALP: alkaline phosphatase; LDH: lactate dehydrogenase; Na: sodium; CRP: c-reactive protein. Significant $p$-values are shown in bold.

The present study had several limitations. The sample size was relatively small, and the study design was retrospective. In addition, a small number of cases lacked information regarding several serum markers. The accrual period was long, and included the era before novel agents for CRPC (abiraterone acetate, enzalutamide, radium-223, docetaxel and cabazitaxel) were introduced. However, an advantage was that this study included only Japanese men with de novo metastasis, which highlighted the similarity among cases.

\section{Conclusion}

This study demonstrated the prognostic significance of ALP, as well as LDH Levels among Japanese men with de novo metastatic HSPC, confirming the universal significance of these serum parameters. However, this study failed to show the significance of other serum parameters among Japanese men, suggesting ALP and LDH values are more robust than other serum parameters.

\section{Conflicts of Interest}

The Authors declare that there are no financial disclosures or conflict of interest regarding this article.

\section{Authors' Contributions}

MS designed the study, and wrote the draft of the article. TK analyzed the data. All other Authors contributed to data collection and interpretation, and critically reviewed the article. EM supervised the study.

\section{Acknowledgements}

The Authors thank H. Nikki March, Ph.D., from Edanz Group (www.edanzediting.com/ac) for editing a draft of this article.

\section{Grant Support}

This work was supported by JSPS KAKENHI grant (17K11145).

\section{References}

1 Shiota M and Eto M: Current status of primary pharmacotherapy and future perspectives toward upfront therapy for metastatic hormone-sensitive prostate cancer. Int J Urol 23: 360-369. 2016. PMID: 27062039. DOI: 10.1111/iju.13091

2 Sweeney CJ, Chen YH, Carducci M, Liu G, Jarrard DF, Eisenberger M, Wong YN, Hahn N, Kohli M, Cooney MM, Dreicer R, Vogelzang NJ, Picus J, Shevrin D, Hussain M, Garcia JA and DiPaola RS: Chemohormonal therapy in metastatic hormone-sensitive prostate cancer. N Engl J Med 373: 737-746, 2015. PMID: 26244877. DOI: 10.1056/NEJMoa1503747

3 James ND, Sydes MR, Clarke NW et al: Addition of docetaxel, zoledronic acid, or both to first-line long-term hormone therapy in prostate cancer (STAMPEDE): survival results from an adaptive, multiarm, multistage, platform randomised controlled trial. Lancet 387: 1163-1177, 2016. PMID: 26719232. DOI: 10.1016/S0140-6736(15)01037-5 
4 Fizazi K, Tran N, Fein L, Mason MD, Dearnaley DP, Spears MR, Ritchie AW, Parker CC, Russell JM, Attard G, de Bono J, Cross W, Jones RJ, Thalmann G, Amos C, Matheson D, Millman R, Alzouebi M, Beesley S, Birtle AJ, Brock S, Cathomas R, Chakraborti P, Chowdhury S, Cook A, Elliott T, Gale J, Gibbs S, Graham JD, Hetherington J, Hughes R, Laing R, McKinna F, McLaren DB, O'Sullivan JM, Parikh O, Peedell C, Protheroe A, Robinson AJ, Srihari N, Srinivasan R, Staffurth J, Sundar S, Tolan S, Tsang D, Wagstaff $\mathrm{J}$ and Parmar MK; STAMPEDE investigators: Abiraterone plus prednisone in metastatic, castration-sensitive prostate cancer. N Engl J Med 377: 352-360, 2017. PMID: 28578607. DOI: 10.1056/NEJMoa1704174

5 James ND, de Bono JS, Spears MR, Clarke NW, Mason MD, Dearnaley DP, Ritchie AWS, Amos CL, Gilson C, Jones RJ, Matheson D, Millman R, Attard G, Chowdhury S, Cross WR, Gillessen S, Parker CC, Russell JM, Berthold DR, Brawley C, Adab F, Aung S, Birtle AJ, Bowen J, Brock S, Chakraborti P, Ferguson C, Gale J, Gray E, Hingorani M, Hoskin PJ, Lester JF, Malik ZI, McKinna F, McPhail N, Money-Kyrle J, O'Sullivan J, Parikh O, Protheroe A, Robinson A, Srihari NN, Thomas C, Wagstaff J, Wylie J, Zarkar A, Parmar MKB and Sydes MR; STAMPEDE Investigators: Abiraterone for prostate cancer not previously treated with hormone therapy. N Engl J Med 377: 338-351, 2017. PMID: 28578639. DOI: 10.1056/NEJMoa 1702900

6 Nuhn P, De Bono JS, Fizazi K, Freedland SJ, Grilli M, Kantoff PW, Sonpavde G, Sternberg CN, Yegnasubramanian S and Antonarakis ES: Update on systemic prostate cancer therapies: Management of metastatic castration-resistant prostate cancer in the era of precision oncology. Eur Urol 75: 88-99, 2019. PMID: 29673712. DOI: 10.1016/j.eururo.2018.03.028

7 Cooperberg MR, Hinotsu S, Namiki M, Ito K, Broering J, Carroll PR and Akaza H: Risk assessment among prostate cancer patients receiving primary androgen deprivation therapy. J Clin Oncol 27: 4306-4313, 2009. PMID: 19667269. DOI: 10.1200/ JCO .2008.21.5228

8 Gravis G, Boher JM, Fizazi K, Joly F, Priou F, Marino P, Latorzeff I, Delva R, Krakowski I, Laguerre B, Walz J, Rolland F, Théodore C, Deplanque G, Ferrero JM, Pouessel D, Mourey L, Beuzeboc P, Zanetta S, Habibian M, Berdah JF, Dauba J, Baciuchka M, Platini C, Linassier C, Labourey JL, Machiels JP, El Kouri C, Ravaud A, Suc E, Eymard JC, Hasbini A, Bousquet G, Soulie M and Oudard S: Prognostic factors for survival in noncastrate metastatic prostate cancer: Validation of the Glass model and development of a novel simplified prognostic model. Eur Urol 68: 196-204, 2015. PMID: 25277272. DOI: 10.1016/j.eururo.2014.09.022

9 Kawahara T, Yokomizo Y, Ito Y, Ito H, Ishiguro H, Teranishi J, Makiyama K, Miyoshi Y, Miyamoto H, Yao M and Uemura H: Pretreatment neutrophil-to-lymphocyte ratio predicts the prognosis in patients with metastatic prostate cancer. BMC Cancer 16: 111, 2016. PMID: 26883640. DOI: 10.1186/s12885016-2134-3

10 Xu L, Zhao Q, Huang S, Li S, Wang J and Li Q: Serum C-reactive protein acted as a prognostic biomarker for overall survival in metastatic prostate cancer patients. Tumour Biol 36: 669-673, 2015. PMID: 25286759. DOI: 10.1007/s13277-014-2670-x

11 Ghoshal A, Garmo H, Hammar N, Jungner I, Malmström H, Walldius $G$ and Van Hemelrijck M: Can pre-diagnostic serum levels of sodium and potassium predict prostate cancer survival?
BMC Cancer 18: 1169, 2018. PMID: 30477464. DOI: 10.1186/ s12885-018-5098-7

12 International Union Against Cancer: Urologic Tumors. Prostate. In: TNM Classification of Malignant Tumors, 5 th edn. Sobin LH, Wittekind CH (eds). John Wiley \& Sons, New York, 170173, 1997.

13 Scher HI, Halabi S, Tannock I, Morris M, Sternberg CN, Carducci MA, Eisenberger MA, Higano C, Bubley GJ, Dreicer R, Petrylak D, Kantoff P, Basch E, Kelly WK, Figg WD, Small EJ, Beer TM, Wilding G, Martin A and Hussain M; Prostate Cancer Clinical Trials Working Group: Design and end points of clinical trials for patients with progressive prostate cancer and castrate levels of testosterone: recommendations of the Prostate Cancer Clinical Trials Working Group. J Clin Oncol 26: 11481159, 2008. PMID: 18309951. DOI: 10.1200/JCO.2007.12.4487

14 Akimoto S, Furuya Y, Akakura K, Shimazaki J and Ito H: Inability of bone turnover marker as a strong prognostic indicator in prostate cancer patients with bone metastasis: Comparison with the extent of disease (EOD) grade. Prostate 38 : 28-34, 1999. PMID: 9973106.

15 He J, Zeng ZC, Yang P, Chen B, Jiang W and Du SS: Clinical features and prognostic factors for patients with bone metastases from prostate cancer. Asian J Androl 14: 505-508, 2012. PMID: 22504872. DOI: 10.1038/aja.2012.24

16 Koo KC, Park SU, Kim KH, Rha KH, Hong SJ, Yang SC and Chung BH: Predictors of survival in prostate cancer patients with bone metastasis and extremely high prostate-specific antigen levels. Prostate Int 3: 10-15, 2015. PMID: 26157761. DOI: $10.1016 /$ j.prnil.2015.02.006

17 Soloway MS, Hardeman SW, Hickey D, Raymond J, Todd B, Soloway S and Moinuddin M: Stratification of patients with metastatic prostate cancer based on extent of disease on initial bone scan. Cancer 61: 195-202, 1988. PMID: 3334948.

18 Imai K, Tomaru Y, Ohnuki T, Yamanaka H, Sakai H, Kanetake H, Minami Y, Nomata K and Saito Y: Significance of a new stratification of alkaline phosphatase and extent of disease in patients with prostate carcinoma with bone metastasis. Cancer 69: 2983-2989, 1992. PMID: 1591692.

19 Shiota M, Yokomizo A, Adachi T, Koga H, Yamaguchi A, Imada $\mathrm{K}$, Takeuchi A, Kiyoshima K, Inokuchi J, Tatsugami K and Naito S: The oncological outcomes and risk stratification in docetaxel chemotherapy for castration-resistant prostate cancer. Jpn J Clin Oncol 44: 860-867, 2014. PMID: 24951829. DOI: 10.1093/jjco/hyu081

20 Okegawa T, Ninomiya N, Masuda K, Nakamura Y, Tambo M, Nutahara K. AR-V7 in circulating tumor cells cluster as a predictive biomarker of abiraterone acetate and enzalutamide treatment in castration-resistant prostate cancer patients. Prostate 78: 576-582, 2018. PMID: 29508425. DOI: 10.1002/pros.23501

21 Yamada Y, Nakamura K, Aoki S, Tobiume M, Zennami K, Kato Y, Nishikawa G, Yoshizawa T, Itoh Y, Nakaoka A, Yoshida E, Uchiyama $\mathrm{T}$ and Honda N: Lactate dehydrogenase, Gleason score and HER-2 overexpression are significant prognostic factors for M1b prostate cancer. Oncol Rep 25: 937-944, 2011. PMID: 21249322. DOI: 10.3892/or.2011.1154

Received April 13, 2019

Revised May 6, 2019

Accepted May 8, 2019 